\title{
The Mysteriousness of The Cultural Space in Peter Mayne's A Year in Marrakesh
}

\author{
Mohammed Saissi \\ Faculty of Arts and Human Sciences in Mohammedia. \\ University of Hassan II in Casablanca, Morocco. \\ Corresponding author: Saissi233@gmail.com.
}

Received: $11 / 29 / 2021$

Accepted:1/16/2022

Published: $2 / 24 / 2022$

\begin{abstract}
:
Peter Mayne's A Year in Marrakesh (1953) places itself as one of the eminent Western travel narratives where the cultural space is constructed through a set of implications that glorify Western Orientalist ideology towards the Orient. Western travel narratives on this region of the world have always been loaded with tremendous representations where the constructed exotic plays a focal role. In his turn, Mayne declares his loyalty to this Western tradition given that his construction of the cultural space in Morocco is totally based on a strand of mysterious and exotic images. Therefore, this paper aims to locate the sites where the cultural space is mysteriously constructed within A Year in Marrakesh providing reasonable interpretations of such embodiment of the exotic. The main question here revolves around the assumption that the cultural space is taken by Mayne as one of the props on which the cultural otherness is contextualized for the sake of constructing the mysteriousness of Morocco. The qualitative methodology is used in this study as long as the ultimate aim is to deeply assess the extent to which the concept of Orientalism appears as a paradigm by which such construction takes place in the novel. The results of this paper highlight an Orientalist manipulation within A Year in Marrakesh by which Peter Mayne misrepresents the cultural privacy of spaces in terms of Hammam and Jamaa el-Fnaa.
\end{abstract}

Keywords: cultural space, travel writing, orientalism, mysteriousness, Morocco

Cite as: Saissi, M. (2022). The Mysteriousness of The Cultural Space in Peter Mayne's A Year in Marrakesh. Arab World English Journal for Translation \& Literary Studies 6(1) 104-116.

DOI: http://dx.doi.org/10.24093/awejtls/vol6no1.8 


\section{Introduction}

Within the framework of Western travel writings on Morocco, the Orientalist propensity has always been a focal feature that encapsulates the construction of the cultural otherness. In this vein, a broad number of both European and American travel writers flocked in the country seeking for a different cultural atmosphere. The cultural difference of Morocco served as a haven where they get "sparked and enlivened by the romance and charm of Moorish culture" (Hibbard, 2004, p. 20) and, eventually, weed out life boredom in their home countries. Their stay in the country resulted in a wide of range of narrative accounts through which their imaginations and insights about the new experienced cultural otherness are expressed and delivered to Western readership. However, their literary engagement with the cultural difference is unfortunately pregnant with a set of misrepresentations and stereotypical images. These memoirs are packed with depictions and visions that either explicitly or implicitly distort the cultural setting of Morocco.

Indeed, Western travel writers like Mark Twain, George Orwell, Paul Bowles, Tennessee Williams, Edith Wharton, Williams Burroughs, Nina Epton, Peter Mayne and many others are categorized as expatriates who constructed a Moroccan cultural otherness based on their ideological and dogmatic beliefs. In this vein, the critical engagement with Western travel writings on the Orient and Africa has justified with evidence that the Orientalist propensity is the main factor leading to such construction. As a paradigm of construction by which the Orient is sentenced to Western cultural distortion and domination, Orientalism within these travel accounts takes different modes in terms of exoticism and romanticism. These modes serve as literary pattern by which the mysteriousness, backwardness, primitivity and inferiority are associated with the Orient. In this sense, it is clear that "the Orient was almost a European invention, and had been since antiquity a place of romance, exotic beings, haunting memories and landscapes, remarkable experiences". (Said,1978, p. 1). Undoubtedly, Said's critical point is projected within most Western travel writings on Morocco given that the country is perceived as a part of the Orient.

Peter Mayne's A Year in Marrakesh is mirror that projects this Orientalist tradition. The novel is entirely allocated to exoticize and primitivize the cultural setting of Morocco. Mayne's literary engagement with Moroccan cultures and lifestyles reflects the extent to which Orientalism is adopted as pattern through which the cultural otherness is exotically constructed. In relation with this, the author's literary engagement with Marrakesh encompasses a set of implications with the intention of exoticizing and primitivizing Moroccan cultural scene. In fact, depictions like those through which the country is introduced as land of superstition, witchcraft, women's oppression and mysterious cultural spaces are all features of Mayne's orientalist leaning.

The main focus in this paper is on Mayne's embodiment of the mysteriousness of the cultural space in Marrakesh. Within this critical reading, the thorny question revolves around the assumption that $A$ Year in Marrakesh is a mirror that reflects how power controls and assesses the construction of space and spatial representations. This Foucauldian philosophy paves the way for another relevant question; to what extent can Orientalism, as a discourse of power, lead Mayne to construct misrepresented and distorted images of the cultural spaces in Marrakesh?

Arab World English Journal for Translation \& Literary Studies 
Therefore, this paper is an attempt to associate Mayne's construction of the cultural space with the Orientalist tendency where the discourse of power gains ground. For this reason, the present paper tries to locate the various sites where the cultural space is exotically depicted, and eventually draw interpretations for such mysteriousness-based construction of the cultural subject in Morocco.

This study's rationale is based on the academic necessity to understand the visions and purposes within Western travel discourse on Morocco. Furthermore, it provides a pathway for those interested in making comparative studies that target classic and contemporary travel narratives on the country. This stems from the belief that most of the present academic studies within the framework of Western travel writings on Morocco address the similarities and changes between the old and new visions and perspectives.

\section{Literature review}

Theoretically speaking, the production of the cultural space occurred as a striking issue within both cultural studies and postcolonial theory. Since 1970, the cultural theory put much focus on the question of space in discourse. Particularly, within the works of Michel Foucault who, in this sense, touched upon the spatial representations and the construction of space by discourse and power. This discourse holds a set of questions where the culture of power and the power of culture are both contextualized within a set of symbols. That is, these symbols are combined together to implicitly shape the binary of the powerful and the powerless. Therefore, it is evident that "space is a significant element of investigation as it unlocks avenues in which power becomes perceptible. Attempting to understand discourses by employing spatial strategic metaphors enhances the grasp of epistemic transformations linked to associations of power". (Raj, 2019, p. 57). According to this, Raj pointed out that the spatial manipulation of discourse is not innocent of the influence of power. Thus, space construction can be one of the facets of the play of power where symbols are gathered to meet a particular endeavor.

The spatial representations implicated within all types of discourses could translate a real or imagined image. Space and discourse unify under the goal of producing a cultural meaning through the practices indulged within representational images of social life. Such intersectional relation specifies the space and categorizes it into a sort of representations that outfit the social and cultural structure as it is ought to be for a specific producer of discourse. Foucault's thesis justifies such approach when he considered power as one of the major factors leading to this spatial construction of the social structure. In this sense, the eye of power, as Foucault called, can easily influence the producer's gaze and; eventually, leads them to exercise the control within a set of representational or symbolic images. That is, the spatial construction is not innocent of the impact of overlapped beliefs that certainly form a particular ideology. Taking this into consideration, the eye of power evidently affects the nature of spatial representations. As a matter of fact, the construction of space appears compatible with the hierarchal relations of power where the constructor decides the nature of the constructed. Therefore, it is true that "space, when regarded as relational, can simultaneously hold different meanings for different individuals...This draws attention to the important role that socio-political power relations play in our subjective experience of place". (Beeckmans, Gola, Singh \& Heynen, 2022, p. 208). This goes against the homage and 
solemnity that space gained in medieval times where it was seen as a stable and fixed construct. This deeply-rooted dogma is, at first, challenged by Galileo who asserted that space is no longer fixed; rather, it moves as time moves. Foucault adopted Galileo's theory for the sake of taking off this medieval concept of space stability. To this end, in his 1967 lecture "Of Other Spaces", he pointed out that "a thing's place was no longer anything but a point in its movement, just as the stability of a thing was only its movement indefinitely slowed down" (Mirzoeff, 2002, p. 230). Accordingly, space is no more than a moving entity; it moves with the movement of its surrounding. Within discourse, space is subject to this theory that power positions itself as a factor leading to the formation of a dominant image of control as long as "the whole problem of the visibility of bodies, individuals, and things, under a system of centralized observation" approved by political authority" (Foucault, 1980, p. 146). Therefore, space can be understood as a manifestation of this doctrine if the spatial construction holds implications that prioritize or eliminate the social structure. The power can be visible within both situations either what celebrates superiority or what declares inferiority. This construction of space is not based on the corporality of its physical components but rather founded on abstract agents in terms of power and authority. These agents result in an arrangement of a set meanings, ideas and images combined altogether with the purpose of bringing the myth of power to the surface. As a matter of fact, it is obvious that the construction of space within discourse cannot be neutral or normal; rather, it has to be based on a set of overlapping considerations that range from one context to another.

Foucauldian philosophical thoughts on spatial representations are validated and adopted by postcolonial theory where colonial discourse is put under critical readings. These studies are conducted for the sake of assessing the extent to which power takes place in the perceptions of the Other colonized. Orientalism, as among the facets of colonial thought, clearly unveils that "the relationship between Occident and Orient is a relationship of power" (Said, 1979, p. 5). This colonial ideology is meant to be translated within Western discourse on East through a set of configurations where racist distinctions are made to differentiate between West and East. That is, the exercise of Western power implicitly means the weakness and the inferiority of East. Such ideology became inevitable for all Western makers of discourse on this area. Notably, they worked on deploying and exalting such dogma whenever and wherever East is addressed within discourse:

Orientalism as a form of thought for dealing with the foreign has typically shown the altogether regrettable tendency of any knowledge based on such hard-and-fast distinctions as "East" and "West": to channel thought into a West or an East compartment. Because this tendency is right at the center of Orientalist theory, practice, and values found in the West, the sense of Western power over the Orient is taken for granted as having the status of scientific truth. (Raj, 2019, p. 73)

In doing so, East is meant to be a metaphor of weakness and a locale where Western power can be exercised. Western discourse On East is allocated to carry out this process by which Eastern societies are sentenced to exoticness that takes varied forms in terms of mysteriousness, primitivity, backwardness, barbarity and all images that synonymize the inferiority. In this sense, the spatial representations are among the tools employed to serve out this Orientalist ideology by which Western discourse achieves its objectives as a discourse that constructs an arbitrary 
distinction between Western geography and Eastern one. The exercise of power within the spatial representations is carried out by "designating in one's mind a familiar space which is "ours" and an unfamiliar space beyond "ours" which is "theirs"'" (Said, 1979, p. 54). Here, it is possible to say that the imaginative space in Western discourse on East is not limited to the geographical division, but also accompanies the cultural, ethic and social boundaries.

Beside the scholarly books, literary works in terms of political letters, journalistic reports and other genres, travel writing can be seen as the most effective channel by which Western discourse exercises its authority, control and power over the Orient. Regardless of the aesthetic motive behind the inclusion of the exotic and its metaphors, which has always been a question of commodification due to the wide consumption of the literature of exoticness by Western audience, the main endeavour within travel books on Orient remains the implementation and execution of the colonial policy:

The idea of travel as a means of gathering and recording information is commonly found in societies that exercise a high degree of political power. The traveller begins his journey with the strength of a nation or an empire sustaining him (albeit from a distance) militarily, economically, intellectually and, as is often the case, spiritually. (Kabbani, 1986, p. 10)

According to the passage above, it is inevitable that Western travel writing has never been innocent of being another mirror that reflects the colonial policy and its imperial ideology towards Orient. For this literary genre, as meant to be for Orientalist discourse as whole, producing an exotic Orient where life appears dark, strange and mysterious comes to the surface as a major feature and, eventually, translates Western imperialist perception of Orient. These representations contribute to the production of unfamiliar images of Orientals and their traditions for Western readers who have never set foot in Orient and, further; reinforce the Orientalist perception they believe in since antiquity:

These Eurocentric representations of non-native people and places that occur in travel writing as well as in novels result in an eroticization of other people. He illustrates, Said, this notion through the traditional Western perspective of the Orient as a strange and mysterious space. (King, 2004, p. 32)

In this vein, Western travel writings on Orient appear as a channel by which culture "becomes a productive site where a plurality of interests are articulated and brought into contact with the kinds of military, economic, and political strategies that produce a complex system of domination." (Behdad, 1994, p. 5) Accordingly, these travel writings represent a network of pictures that depict the extent to which the power guides Western myth and glorifies Westerns' imaginary and biased perception of Orient.

On the same basis, and in accordance with Foucault's theory on space, knowledge and power as it is elaborated by postcolonial theory, Western travel writings on Orient incorporate the cultural space as a locale characterized with its exoticness and mysteriousness. The Orientalist leaning has always been a focal feature that "as one screens guidebooks and travel journals, one is 
immediately struck by the recurrence and preponderance of some ideas which smack of Orientalism, paternalism and exoticism". (EL Hayani, 2020, p. 66). In this regard, it is important to point out that the cultural space in the Orient appears in these travel memoirs as micro image of the macro one given to the geographical space as whole. In doing this, the spatial representations of mysteriousness take two dimensions; the first is manifested in horizontal perspectives ascribed to Eastern societies as whole; at times, this concerns specific societies or countries, while the second is carried out through vertical perspectives where this mysteriousness is headed towards very specific cultural spaces. In focus on the vertical spatial representations within Western travel writings on Orient, the cultural space, as a figure of mysteriousness, appears to have received a set of implications that canonize the orientalist perception. Consequently, the traditions and practices that Orientals use to carry out through specific spaces are exposed to biased portrayals. Here, it is also important to conclude that the cultural space within these accounts is produced on the basis of emotional sense where-by the outcome comes aligned with what Western travel writers feel and imagine, basically, with what they decide. To clearly illustrate this point, in 1979, Said pointed out that:

The objective space of a house--its corners, corridors, cellar, room--is far less important than what poetically it is endowed with, which is usually a quality with an imaginative or figurative value we can name and feel: thus a house may be haunted, or homelike, or prisonlike, or magical, so space acquires emotional and even rational sense by a kind of poetic process, whereby the vacant or anonymous reaches of distance are converted into meaning for us here. (p. 55)

This justifies the thesis that spatial representations do not necessarily picture the truth, rather; they can be a translation of the author's ideological background; which is, in this case, an ideology based on stereotypes and prejudices against all what is meant to be Oriental. The exotic as mysterious is, consequently, an implication by which the cultural space in Orient approached within Western travel writings on the region. In this regard, this mysteriousness and outlandishness accompanied Western travel literature on Orient during $18^{\text {th }}$ and $19^{\text {th }}$ centuries where-by the romantic and sensual are implicated to configure the Oriental exoticness. Within these accounts, for most European travel writers "the exotic Orient was represented and conceived as a locus of romance, sensuality and idleness" (Agliz, 2015, p. 3). In doing so, the cultural space meant to be constructed in accordance with this conception in mind. Hence, a cultural place has to be romantic and sensual through the inclusion of erotic. A case in point here concerns William Makepeace Thackeray's letters on Orient which followed his travel experience to Turkey and Egypt in the middle of $19^{\text {th }}$ century. Through one of his narrative scenes, Thackeray intervened the cultural singularity of Turkish bath in attempt to construct its mysteriousness whereby it is introduced as a cultural space that secures the access to a realm of romance and sensuality:

When the whole operation of the bath is concluded, you are led with what heartful joy I cannot say softly back to the cooling room, having been robed in shawls and turbans as before. You are laid gently on the reposing bed, somebody brings a narghile, which tastes as tobacco must taste in Mahomet's paradise, a cool sweet dreamy languor takes possession of the purified frame, and half an hour of such delicious laziness spent over the pipe as is unknown in Europe, where vulgar prejudice has most shamefully maligned indolence, calls 
it foul names, such as the father of all evil, and the like, in fact, does not know how to educate idleness as those honest Turks do, and the fruit which, when properly cultivated, it bears. The after bath state is the most delightful condition of laziness, I ever knew, and I tried it wherever we went afterwards on our little. (Thackeray, 2006, p. 62)

Much focus here is on the excitement provided by Turkish bath whereby the descriptions of the place are encapsulated with a sense of romance. Thackeray's production of the sensual and the romantic emerges through the inclusion of implications of several images exemplified in the use of the narghile, the cooling room, the heartful joy and other ingredients that exoticize and romanticize the scene. After all, for him, the mysteriousness of this cultural place is exemplified by these pictures where the aim remains the configuration of a space that validates Western vision on Orient as whole.

Within Western travel writings, the spatial representations of culture played an important role in the consecration and the glorification of the Orientalist ideology. The history of these writings validates this propensity as long as most of Western travel writers who experienced Orient. Epic Western journeys, like those of Montague, Montesquieu, de Nerval, Bowles, Flaubert and many others, were all recorded within travel narratives that exoticize and romanticize the Oriental regions they set feet in. For instance, Gustave Flaubert confirmed this Orientalist fashion through his travel account released in 1851 after his 1841 journey through Cairo and Beirut. The passage above, not unique to, shows how Flaubert describes the Pyramids' scene, mainly the Sphinx (Archaeological Site in Giza, Egypt) with a hair-raising tone looking at the scary picture he drew when narrating his experience with this historical and cultural space in Egypt:

View of the sphinx Abou-el-Houl (the father of terror). The sand, the pyramids, the sphinx, all gray and drowned in a large pink tone; the sky is all blue, the eagles hover slowly around the top of the pyramids. We stop in front of the sphinx, he looks at us in a terrifying way; maxim is quite pale, I'm afraid my head will spin and I try to control my emotion. We set off again at full speed, mad, carried away among the stones; we walk around the Pyramids, at their very foot, at a walk. The luggage is slow to come, night is falling. (Le Calves, 2004, p.451)

Here, the mysteriousness of the space is exemplified by the constructed image of horror; the image that is meant to be displayed by the author. His Orientalist leaning is evident given that he purposely ignored the identification of the pyramids as a cultural space that reflects the history and cultural heritage of Egypt. By doing this, the author looks loyal to his Western style whereby the cultural is turned into the mysterious with the purpose of constructing a realm of mysteriousness. Flaubert remains eminent whenever Western travel writings on Orient are issued. This is resulted from his extreme engagement in the exoticness-based production of Orient in $19^{\text {th }}$ century.

The constructed mysteriousness of the cultural space can be seen as a wise Orientalist tool. That is, the process of exoticizing a particular cultural space is not limited to what is inside its physical borders. It is implicitly a construction of the social and cultural setting to which this space belongs. This stems from the constant fact that every cultural space is a convergence where a set 
of cultural and social practices, beliefs and customs meet together. As a matter of fact, "no space is innocent or pure, that all spaces are inscribed through and through by societal ideology, that every society produces certain spaces, its own spaces, which define and describe that particular society and its specific set of social relations". (Narayanan, 2022, p.29). With this in mind, Thackeray's engagement with Turkish bath is considered as an engagement with Turkish society as whole. In fact, by associating this cultural space with romance and sexuality, he introduces Turkey as a haven where sensuality and immorality are unrestricted and allowed. It is also the case of Flaubert's engagement with the Pyramids and the scary picture constructed while describing the Sphinx. By doing this, the author secures the exotic shape of Sphinx and implicitly constructs an image of horror that would undoubtedly remain linked to Egyptian culture.

It is lucid now that the cultural space in Orient witnessed a series of misrepresentations with Western travel writings since. With this in mind, Western travellers to the area put focus on the cultural space by which the production of exoticness can take varied forms of mysteriousness. What is fundamental for these travel writers is being in a total alignment with the widespread public ideology in West; the ideology inherited from the translation of Arabian tales and later, reinforced by the exigencies of colonialism.

With the purpose of meeting the aim of this study, the studies above are not enough to make clear interpretations of the constructed mysteriousness of the cultural space within Western travel writings on the Orient. This reflects the literary gap within the present literature on the Orientalist propensity in Western travel discourse on the Orient. Therefore, there is a necessity to create a solid scientific platform so that further academic inquiries related to this research area can come up with sufficient findings.

\section{Analysis}

As far as the above deals with a couple of representations of the cultural space set by two eminent Western writers within the archive of travel narratives, this section is concerned with assessing some of the sites where the cultural space is led to mysteriousness within Peter Mayne's A Year in Marrakesh. In fact, Mayne penetrates the cultural spaces in Marrakesh in attempts to display an Orientalist picture that satisfies his aspiration and feeds up his readership's desire to known about the exotic and the mysterious. For instance, as meant to be produced within Thackeray's letters on Orient between 1841 and 1846, Turkish bath, as known for Hammam in Morocco, is portrayed as an exotic space marked with a couple of mysterious practices. Mayne takes no notice of Hammam as a space with a real cultural significance besides being an outlet where people take a public steam bath. Further, he ignores the embodiment of the religious value of this space looking at its association with Islam world and its historical significance as inherited from Roman Empire. On the contrary, the author declares his Orientalist attitudes once he steps in Hammam with his Moroccan friend Abdeslem. The latter's intention is leading his foreign friend to know about this cultural place and get familiar with it, but the author's reaction appears pessimistic looking at the biased descriptions he makes to portray the place. The following passage can be taken as a case in point:

Arab World English Journal for Translation \& Literary Studies 
In the semi-darkness I could see nothing at first, but the place was filled with sounds, echoing and ricocheting round the walls. Men were calling to each other. I could hear running water, the clatter of buckets, a strange slapping noise. Gradually my eyes became more used to the darkness and I could make out a low, vaulted ceiling. Such light as there was flowed out from an embrasure, in a horizontal semi-opaque veil below which men lay naked and relaxed in the obscurity. Already I had lost 'Abdeslem, but he reappeared in a moment, carrying his two buckets filled with water. (Mayne, 2002, pp. 88-89)

Mayne's first encounter with Hammam gives birth to a set of implications through which he exotically constructs a set of spatial representations. Indeed, such embodiment is carried out to create the mysteriousness of the space which takes different forms in terms of darkness, noise, and nakedness. Anthropologically speaking, Hammam is seen as a social institution where many relationships take place. However, the author appears loyal to Western Orientalism whereby the unfamiliarity of Oriental places occurs as a mode of representations within Western writings. Such mode goes back to Victorian era at the time when travel writers were eager about romanticizing and exoticizing all what belongs to Orient. In fact, with the intention of feeding their readers imaginations, these writers adjusted their perceptions to the Arabian tales as meant to be translated in early $18^{\text {th }}$ century. Consequently, "writing about hamams, harems and other places unfamiliar to Europe by describing such places as dreamy, mystical, exotic, heavenly and sublime were rather Orientalist clishés of describing the Other" (Franchi \& Mutlu, 2018, p. 74). Mayne's descriptions of Moroccan Hammam respond to this Orientalist tradition which is confirmed by other scenes where he narrates how he stands marveled at some of the customs that Moroccans practice in such a place:

The floor was littered with bodies. Some were stretched flat, some squatted, many were being massaged or were themselves massaging their next-door neighbours. I felt stupidly shy. My skin seemed too white, and of a strange luminosity in this world of darkness and bodies the colour of dusk. I didn't belong here, and my sponsor was nowhere to be found. I longed to find myself a corner and to sit cloaked in obscurity, but the whole wall space was occupied and I could only stand unhappily. (Mayne, 2002, p. 70)

The rhetoric of the mysterious of the cultural space in Morocco, as clearly manifested in the production of Moroccan public bath, is not only an outcome of the deeply rooted ideology of Orientalism, it is also a mirror that reflects the Western perception of the African mindset. As widely known in the community of literary criticism, European travel writings on Africa, since $15^{\text {th }}$ century, have always been concerned with the consecration of the primitiveness and the darkness of Africans and their life. Later along with the emergence of European colonial enterprise in Africa, which witnessed its peak in $20^{\text {th }}$ century, the consecration of the primitiveness and darkness within Western travel accounts appeared as a fundamental tool. In this vein, the cultural identity of Africa is led to elimination and distortion that many customs and traditions are sentenced to primitivity and backwardness. Consequently, as meant to be for Joseph Conrad's The Heart of Darkness (1899) and Rider Haggard's King Solomon's Mines (1885), the images drawn on Africa within these accounts are a mixture of both early imaginations and imperial interests;

Arab World English Journal for Translation \& Literary Studies 
then, it becomes a compulsory task for all European travel writers who flocked in the area; if not, their accounts step out of reality, the reality that West believes in, consecrates and develops:

Stories of African travel were known to European travellers when they arrived in Africa from the fifteenth century. While the travel writing they produced in subsequent centuries was not always straightforwardly pro-imperialist, it nonetheless often developed what Mildred Mortimer calls 'fictionalized stereotypes' about Africa, centred particularly on primitivism and darkness. (Jones, 2019, p. 284)

The quotation above clearly justifies the claim that Africa appears as a site of the exotic within Western travel accounts since antiquity. It is true that Morocco shares many of its cultural characteristics with Africa; the continent to which this country belongs. Nevertheless, it is known for a unique cultural identity where a mixture of many relationships takes place. This cultural singularity is an accumulation of overlapping beliefs, traditions, language and, values whereby languages, geography, history, and religions meet together. Some of these props belong to Africa. however, this does not necessary mean that Morocco is a country with a total African cultural identity. On the other hand, even if it is assumed that Moroccan culture is completely African, this does not justify the claim that it is primitive and dark as long as Africa itself is sentenced to cultural distortion within these travel accounts. Mayne's distortion of the cultural space in Marrakesh is a translation of this European dogma as it is confirmed with some of the implications when he narrates "under this African sun the saxon resembles the fatty parts of cold mutton" (Mayne, 2002, p. 40) and also "perhaps they felt out of things on this mad African place" (p. 128) Therefore, the Africanity of Morocco is undoubtedly existing in Mayne's mind; eventually, it is what drives him to stereotype and misrepresent the cultural spaces in Morocco as meant to be in the case of Moroccan Hammam.

Mayne's intention to misrepresent to the cultural spaces in Marrakesh is not limited to the case of Moroccan hammam. Another case in point here is the square of Jamaa el- Fnaa which is a place frequented by locals and visitors thanks to the excitement it offers. Since its emergence in $11^{\text {th }}$ century, beside its commercial status as a market that offers different categories of products for the visitors; basically, antiques and artisanal products, the place is known for its symbolic role as it plays its cultural role as one of the spaces where Moroccan traditions and customs are performed through music, clothes, religion, food and celebrations. However, this invaluable cultural value is eliminated by Mayne who, rather, tends to create a sort of deterioration of the place through introducing it as a mysterious site where many exotic practices take place. In doing so, Mayne provides many scenes that depict his Orientalist configuration as obviously detected when he narrates:

I wandered through the crowds, peeping over shoulders into the whirlpools, seeing nothing any more but the faces and whatever they happened to be watching. It was simply a fairground again: singers, an ostrich standing among the bones of its fellows, a woman who drinks boiling water from a kettle to the accompaniment of flutes. Boys - Chleuhs, someone told me - like little white mice pirouetting and squeaking and clinking their minute finger cymbals. Charlatans of all sorts. It is a long list. (Mayne, 2002, p. 24) 
Mayne sees Jamaa el- Fnaa as place full of mysteriousness which is, for him, exemplified in many pictures that introduce it as site where the crowed, fairground, animals, charlatans, and other people with strange practices gain ground. Still, his misrepresentations are even extended to cover boys who frequently come to the square picturing them as "little white mice pirouetting and squeaking and clinking their minute finger cymbals." (Mayne, 1953, p. 24). Through the inclusion of such images, Mayne designs a negative picture of Jamaa el-Fnaa whereby the readership is led to one ultimate conclusion that remains the savagery of the place. In this sense, the square is meant to be a threatening locale instead of being a site where visitors enjoy and learn about Moroccan traditions and customs. The author's desire to distort the cultural position of Jamaa el- Fnaa is, consequently, quite obvious. This is confirmed with another scene via which he points:

I am frequently on the Djema'a el-Fna. I believe I know almost all the 'acts' by now and a good many of the djellaba-hoods that gather round them - by sight, I mean. There is a huge floating population in Marrakesh, as you would expect of this market for the great south, and at any given moment there are thousands and thousands of strangers in town. But there are hundreds of inhabitants too who seem to do no work and are always to be seen on the place. In a strange, inarticulate sort of way I have become friendly with a family of acrobats that performs every evening. It is only here that I see them. They wear professional costumes vaguely. (Mayne, 2002, p. 34)

The passage above clearly reveals Mayne's mode of representation that remains full of prejudices and stereotypes against all what can give an objective image of Jamaa el- Fnaa square. Again, the mysteriousness of the space is built up throughout images of distortion. To this end, it is represented as a locale for strange visitors who have nothing to do; and, as a stage on which acrobats perform their works wearing vague clothes. In fact, the strangeness of the visitors and the vagueness of the acrobats are the signs of this mysteriousness that the author decides to associate with the square.

As it obvious through Moroccan Hammam and the square of Jamaa el-Fnaa, Mayne's spatial representations cannot be categorized as objective. His opts for a subjectivity that adjusts to his Western ideology whereby Orient and Africa are geographies of mysteriousness, primitivity, savagery and all what can be a metaphor of the uncivilized. In general, this ideology can be seen as a standard mode by which the cultural object is distorted. In particular, the cultural space has to be covered with such misrepresentations as long as it gathers a couple of traditions and practices. It is, then, a booty that offers a serious opportunity for Western travel writers who, undoubtedly, find it a fertile soil where their Orientalist ideas can be planted. Following such approach, the spatial exoticness included by Mayne within A Year in Marrakesh justifies the claim that power is a Western dogma imposed through travel discourse on the Orient and Africa. Morocco, as a part of this area, is conceived on this basis whereby its cultural space is denied and dismissed. After all, it is exactly what Foucault goes to when he argues that:

Space used to be either dismissed as belonging to 'nature' - that is, the given, the basic conditions of 'physical geography', in other words a sort of 'prehistoric' stratum; or else it 
was conceived as the residential place or field of expansion of peoples, of a culture, a language or a State. (Foucault, 1980, p. 149)

Such idea is trigged within Behdad's Belated Travelers: Orientalism in the Age of Colonial Dissolution (1994). Through his chapter "From travelogue to Tourist Guide: The Orientalist as Sightseer", Behdad sees that the exoticness of the Other becomes an object of desire for belated travellers whose endeavour is the commodification of Orient. That is, the travel book is turned into a guide that leads "to identify the already defined signs of exoticism as exotic" (Behdad, 1994, p. 48) It is, then, a second exoticizing of the Oriental culture as long as the first is carried out by earlier travellers while the second is by belated ones who only search for the commodification of this imaginary exoticness. In both of the cases, the discourse of power remains a pathway through which the cultural domination is declared within Western travel writings on Orient:

Although the promotion of the Oriental culture as an exotic commodity is intertwined with the relations of colonial power, the discourse of tourism suggests a passage in Orientalist vision from perceiving the orient as the object of cultural domination to seeing it as an object of desire. (Behdad, 1994, p. 48)

According to Behdad, Western travel discourse turned the Orient into an object by which the cultural domination is given a sense. Undoubtedly, Peter Mayne, through his misrepresentations of the cultural space in Marrakesh, adopts the same basis of such manipulation. Eventually, his spatial engagement with the cultural subject in Morocco is an outcome of a set of factors that vary from the ideological, across the colonial to the aesthetic. In all the cases, power imposes itself as transversal dogma that leads to exercise such cultural hegemony within Mayne's travel account on Morocco.

\section{Conclusion}

This critical engagement with Mayne's A Year in Marrakesh is centred on the author's embodiment of the cultural space in Marrakesh. It is concluded that this construction is featured with the inclusion of mysteriousness as a feature that marks cultural space like Hammam and the square of Jamaa el-Fnaa. To this end, the author's descriptions of the varies sites he experienced in Marrakesh are characterized with a set of biased visions where the exotic declares itself as a distinct mode of representations. Indeed, weird and strange images are purposely indulged with the aim of coping with the same tone that covers the different parts of this travel narrative. Undoubtedly, as reflected with the section of analysis, the cultural space in Marrakesh, as implicitly in Morocco, is constructed and manipulated in accordance with Mayne's orientalist gaze where all what belongs to the Orient has to be introduced unfairly. Looking at this in mind, Peter Mayne is an Orientalist travel writer par excellence. His loyalty to the Orientalist paradigm reflects with evidence his eye of power within the constructed cultural spaces. Therefore, the cultural symbols inserted by Mayne are objects and tools by which the mysteriousness of these spaces is secured and validated. After all, the Orientalist dogma is evidently behind his biased perception of, not only the cultural spaces, but also all the whole cultural setting of Morocco. As a matter of fact, A Year in Marrakesh is another travel account that classifies its author as one of the eminent Orientalist travel writers who flocked in the country. 


\section{About the author:}

Mohammed Saissi is a Ph.D. researcher at the Faculty of Arts and Humanities in Mohammedia, Hassan II University in Casablanca, Morocco. His major research areas are Literary theory, Postcolonial studies, Cultural studies, and Travel literature. ORCID: https://orcid.org/0000-00023635-5466.

\section{References}

Agliz, R. (2015). Morocco as an Exotic and Oriental space in European and American Writings. Arab World English Journal, (Special Issue on Literature No. (3).29-44.

Allen, H. (2004). Paul Bowles: Magic and Morocco. San Francisco: Cadmus Editions.

Al Hayani, K. (2020). Marrakesh in Travel Literature. International Journal of Innovative Science and Research Technology, 5 (7) 166-169.

Beeckmans, L. Gola, A. Singh, A. \& Heynen, H. (2022). Making Home(s) in Displacement: Critical Reflections on a Spatial Practice. Belgium: Leuven University Press.

Behdad, A. (1994). Belated travellers: Orientalism in The Age of Colonial Dissolution. Durham and New York: Duke University Press.

Foucault, M. (1980). Power/knowledge: Selected interviews and other writings 1972-1977 (Colin Gordon, Leo Marshall, John Mepham \& Kate Soper). New York: Pantheon Books.

Franchi, B., \& Mutlu, E. (2018). Crossing Borders in Victorian Travel: Spaces, Nations and Empires. United Kingdom: Cambridge Scholars Publishing.

Le Calves, E. (2004). Gustave Flaubert: A Documentary Volume. Michigan: Gale Publishing. Jones, R. (2019). African Travel Writing. United Kingdom: Cambridge University Press.

Kabbani, R. (1986). Europe's Myths of Orient. London: Palgrave MacMillan.

King, R. A. (2004). Border Confluences: Borderland Narratives from the Mexican War to the Present. United States: University of Arizona.

Mayne, P. (2002). A Year in Marrakesh. London: Eland Publishing.

Narayanan, M. (2022). Space, Time and Ways of Seeing the Performance Culture of Kutiyattam. London \& New York: Routledge.

Nicholas, M. (2002) The Visual Culture Reader. London and New York: Routledge.

Raj, P. E. (2019) Foucault and Spatial Representation. PILC Journal of Dravidic Studies, 3(1) 57 75.

Said, E. W. (1979). Orientalism. New York: Vintage Book.

Thackeray, W. M. (2006). Notes of a journey from Cornhill to grand Cairo. England: Oxford University. 